\title{
PENERAPAN SISTEM PEREKONOMIAN SYARIAH DALAM MENGATASI KESENJANGAN SOSIAL EKONOMI DI INDONESIA
}

\author{
Nur Azmil Islahiha, Nur Frita, Reza Maulana \\ nur.azmil@gmail.com \\ Mahasiswa Fakultas Agama Islam Universitas Ibn Khaldun
}

\begin{abstract}
ABSTRAK
Salah satu yang menjadi permasalahan utama hampir di setiap negara terutama Negara berkembang adalah masalah kesenjangan. Kesenjangan dapat terjadi dalam segala aspek sosial, hal ini disebabkan karena ketidakmerataan pendistribusian. Kesenjangan biasanya terjadi pada ketidakmerataan pendistribusian aspek-aspek perekonomian sehingga muncullah istilah kesenjangan sosial ekonomi. Penelitian ini bertujuan untuk menganalis kesenjangan sosial ekonomi di indonesia beserta solusinya menurut tinjauan sistem ekonomi syariah. Penelitian ini di laksanakan dengan kajian kepustakaan dari sumber-sumber literasi yang terkait dan relevan. Berdasarkan hasil penelitian muncullah kesimpulan bahwa Ketidakmerataan pendistribusian terjadi karena adanya ketidakterbatasan hak kepemilikan pribadi dalam sistem perekonomian konvensional sehingga alur pendistribusian tidak dapat berjalan dengan semestinya. Oleh karenanya perlu diperhitungkan penerapan ekonomi syariah sebagai salah satu solusi untuk dapat meratakan pendistribusian secara sendirinya salah satunya melalui kebijakan zakat, infak, dan sedekah.
\end{abstract}

Kata Kunci: Kesenjangan sosial ekonomi, pertumbuhan, perkembangan, sistem perekonomian, ekonomi syariah, ketidakmerataan, ketidakseimbanagan.

\section{PENDAHULUAN}

\section{Latar Belakang Penelitian}

Sektor perekonomian merupakan salah satu elemen penting penunjang kehidupan, yang mana dalam keseharian manusia tidak akan bisa di pisahkan dengan perekonomian. Namun, sektor perekonomian ini perlu mendapatkan perhatian lebih dari setiap manusia karena sektor ini terbilang cukup rapuh, seringkali timbul berbagai permasalahan, konflik, dan perpecahan karena sektor perekonomian. Salah satu contoh permasalahan yang sering kali muncul dan menimbulkan dampak negative dalam kehidupan bermasyarakat adalah permasalahan kesenjangan sosial ekonomi.
Kesenjangan sosial ekonomi merupakan permasalahan global yang melanda berbagai negara terutama pada negara yang masih berkembang. Bahkan permasalahan ini telah menjadi pembahasan utama untuk menetapkan kebijakan perekonomian di berbagai negara sejak dahulu kala. Hal ini dikarenakan seringkali kebijakan pembangunan yang telah ditetapkan untuk meningkatkan pertumbuhan ekonomi di suatu negara, justru memperburuk kondisi kesenjangan sosial ekonomi pada negara tersebut. Masalah ini merupakan sesuatu yang tugas besar bagi pemerintahan di kebanyakan negara termasuk Indonesia, 
yang seharusnya membutuhkan perhatian lebih.

Salah satu faktor yang pastinya menjadi penyebab dari seluruh kesenjangan yang ada baik itu kesenjangan pendidikan, sosial ekonomi dan lainnya adalah faktor ketidakmerataan distribusi sehingga menyebabkan beberapa pihak masyarakat di untungkan sementara pihak lain di rugikan. Ditambah lagi sistem ekonomi kapitalis yang kita anut selama ini ternyata banyak berkontribusi dalam kehancuran perekonomian terutama masalah kesenjangan sosial ekonomi. Karena sistem ekonomi konvensional membebaskan hak kepemilikan pribadi atas segala sesuatunya, hal ini dapat menggangu alur perputaran distribusi karena dengan kebebasan tersebut mereka yang di untungkan akan semakin berada di atas dan timbulah jurang pemisah yang semakin melebar, yang kaya akan semakin kaya dan yang miskin menjadi semakin miskin karena terganggunya alur distribusi.

Salah satu aspek yang seharusnya dapat dipertimbangkan untuk mengatasi kesenjangan yang ada adalah dengan menerapkan sistem perekonomian syariah. Ekonomi syari'ah merupakan sistem yang diyakini oleh peneliti dapat menciptakan suatu stabilitas dalam perekonomian dan dapat menjadi solusi dari permasalahan kesenjangan sosial ekonomi, kerena didalamnya terdapat banyak sistem dinilai dapat melakukan pendistribusian secara merata.

Berdasarkan uraian diatas akan dilakukan sebuah penelitian untuk melihat aspek-aspek terkait kesenjangan sosial ekonomi di Indonesia, dan selanjutnya perlu di lihat pula ekonomi syariah sebagai salah satu solusi bagi kesenjangan sosial ekonomi di Indonesia.

\section{Perumusan Masalah}

Berdasarkan berbagai uraian latar belakang diatas, dapat disusun rumusan masalah yang sekiranya perlu untuk diidentifikasi kemudian dikaji secara mendalam mengenai penelitian yang sesuai. Adapun rumusan masalah yang sesuai dengan hal tersebut adalah

1. Seperti apakah realita serta sebab dan akbibat yang timbul dari kesenjangan sosial ekonomi di indonesia?

2. Bagaimana sistem perekonomian syariah dapat menjadi solusi unuk meminimalisir permasalahan yang di timbulkan dari adanya kesenjangan sosial ekonomi di Indonesia?

\section{Tujuan Penelitian}

Tujuan penelitian ini berkaitan dengan upaya untuk menyelesaikan permasalahan berdasarkan berbagai uraian yang mendasari diadakannya penelitian. Maka yang menjadi tujuan dari penelitian ini adalah

1. Mengidentifikasi realita kesenjangan sosial ekonomi di Indonesia beserta sebab dan akibat dari kesenjangan sosial ekonomi tersebut

2. Mencari cara yang efektif untuk meminimalisir permasalahan yang di timbulkan dari adanya kesenjangan sosial ekonomi di Indonesia berdasarkan sistim ekonomi syariah

\section{Ruang Lingkup Penelitian}

Agar aspek yang menjadi pembahasan dalam penelitian ini lebih terarah dan tidak meluas maka peneliti membatasi dan mempersempit permasalahan dengan batasan sebagai berikut:

1. Penelitian ini hanya difokuskan pada kesenjangan sosial ekonomi secara global (tidak terperinci), disertai faktor- 
faktor umum yang menjadi penyebab dan solusi yang di sajikan sistem perekonomian syariah terhadap permasalahan kesenjangan sosial ekonomi Indonesia.

\section{TINJAUAN TEORITIS}

\section{Kesenjangan Sosial Ekonomi}

Kesenjangan Sosial adalah suatu ketidakseimbangan dalam berkehidupan sosial masyarakat sehari-hari, baik individu maupun kelompok, dimana terjadi ketidakadilan, ketidaksetaraan dakam pendistribusian hal-hal atau aspek yang dianggap penting dalam suatu masyarakat pada umumnya. Kesenjangan sosial seringkali disangkut-pautkan dengan adanya perbedaan yang mencakup kekayaan harta, jasa, barang dan lainnya, dari suatu pihak dalam masyarakat terhadap pihak lainnya sehingga muncullah istilah kesenjangan sosial ekonomi. Jadi dapat disimpulkan bahwa kesenjangan sosial ekonomi adalah suatu keadaan dimana pihak masyarakat tertentu tidak dapat menerima adanya perbedaan dengan pihak lainnya, prihal aspek-aspek yang berkaitan dengan perekonomian atau adanya dampak negative dari perbedaan tersebut.

Kesenjangan sosial ekonomi umumnya terjadi antara pihak masyarakat yang berpendapatan tinggi dengan pihak masyarakat berpendapatan rendah. Hal tersebut pada dasarnya hampir tidak dapat dihilangkan dan dihindari melainkan hanya bisa di minimalisir sampai sekecil mungkin sehingga tidak menjadi sesuatu yang dapat dipermasalahkan dan dapat di terima oleh masyarakat pada umumnya. Karena sangat tidak mungkin seluruh orang dalam suatu masyarakat mempunyai pendapatan yang sama rata. Hal tersebut dapat dilihat dari adanya peluang dan manfaat yang tidak
2. Penelitian ini lebih banyak dilakukan mengunakan kajian kepustakaan atau literasi. sama untuk kedudukan sosial yang berbeda dalam bermasyarakat. Karenanya bukanlah suatu hal yang aneh jika masalah kesenjangan itu akan selalu ada hampir di setiap wilayah, tidak memandang wilayah apakah itu, baik itu di negara yang sedang berkembang, atau bahkan di negara yang mengalami kemajuan.

\section{Perkonomian Syariah}

\section{Hakikat Ekonomi}

Pada dasarnya aspek konomi ialah salah satu dari sekian banyak aspek penting yang menunjang kehidupan dalam keseharian manusia. Aspek ini melibatkan adanya kegiatan interaksi antara suatu pihak dengan pihak lainnya yang samaasama mempunyai tujuan untuk memenuhi kebutuhan hidup mereka sehari-hari. Ekonomi merupakan salah satu aktivitas yang berhubungan dengan produksi, distribusi, dan konsumsi terhadap barang dan jasa yang dibutuhkan demi keberlangsungan hidup manusia. Istilah "ekonomi" berasal dari bahasa Yunan yang tersusun dari dua kata yaitu "oikos" yang maknanya "rumah tangga, keluarga", serta "nomos" yang bermakna "aturan, hukum" sehingga dapat diartikan sebagai "aturan rumah tangga" Sedangkan yang dimaksud dengan ekonom atau ahli ekonomi adalah orang menerapkan dan memahami aspek yang berkaitan dengan konsep ekonomi dalam pekerjaannya.

Aktivitas ekonomi atau kegiatan ekonomi adalah segala sesuatu yang dikerjakan untuk menghasilkan pendapatan 
dalam guna memenuhi kebutukan hidup. Kegiatan ekonomi pada umumnya mencakup sektor produksi, distribusi serta konsumsi. Kegiatan ekonomi merupakan suatu hal yang tidak dapat dipisahkan dari kehidupan keseharian manusia. Seiring dengan berkembangnya zaman, tentunya kebutuhan manusia terhadap sektor ekonomi akan bertambah oleh karenanya sektor ekonomi secara terus-menerus akan mengalami pertumbuhan dan perubahan.

\section{Sistem Perkonomian}

Secara global, penerapan ekonomi dalam kehidupan keseharian manusia tertata dalam sebuah tatanan sistem. Terdapat dua sitem yang sering menjadi perdebatan dan perbandingan para ekonom antara sistem yang satu dengan sistem yang lain, yaitu sistem ekonomi konvensional dan sistem ekonomi syariah. Secara garis besar perbedaan yang paling menonjol antara sistem ekonomi konvensional dan sitem ekonomi syariah adalah prihal hak kepemilikan pribadi. Dalam sistem ekonomi konvensional hak kepemilikan pribadi cenderung bersifat bebas, tanpa ada batasan, sistem ini beranggapan bahwa ada keterkaitan antara kebebasan perekonomian, dengan kemakmuran dan kesejahteraan masyarakat dalam wilayah yang menganut sistem ekonomi kapitalis, karena realita dari negara-negara yang menganut sistem ekonomi kapitalis mayoritasnya adalah negara yang makmur dalam segi perekonominnya, salah satu contoh dari negara-negara tersebut adalah Amerika Serikat.

Sedangkan sebaliknya sistem ekonomi syariah cenderung mengatur batasan pada hak kepemilikan pribadi. Sistim ini berpendapat bahwa dengan adanya kebebasan hak kepemilikan pribadi dapat membuat kelompok masyarakat kaya semaikin bertambah kaya dan kelompok masyarakat miskin semakin miskin, dan timbulah kesenjangan antara masyarakat miskin dengan masyarakat kaya yang semakin jelas.

Baik sisitem ekonomi konvensional maupun sistem ekonomi syariah, keduanya sama-sama mempunyai prinsip, landasan, dan tujuannya masing-masing yang memperkuat keberadaan sistem mereka.

\section{Ekonomi Syariah}

Ekonomi syariah atau yang sering disebut juga dengan Ekonomi Islam adalah suatu bentuk percabangan dari ilmu ekonomi yang berdasarkan pada ajaran serta nilai-nilai keislaman. Sistem ekonomi syariah memiliki beberapa hal pokok yang dijadikan landasan hukum yaitu, Al Qur'an dan As Sunnah Rasulullah SAW. Selain landasan hukum pokok ada juga landasan hukum yang bersifat melengkapi, yaitu Qiyas dan Ijma' yang mana pada dasarnya kedua hal ini juga merujuk dari Al Qur'an dan As Sunnah.

Hukum-hukum yang mendasari berbagai kegiatan transaksi berbasis ekonomi syariah sepenuhnya dijalankan untuk kemaslahatan masyarakat pada umumnya. Kesejahteraan masyarakat dalam perekonomian syariah tidak diukur dari aspek-aspek nyata atau materil saja, namun juga mempertimbangkan dampaknya pada lingkungan, serta dampak berupa sosial, mental dan spiritual. Ekonomi syariah memiliki tujuan utama yaitu untuk meraih falah, yang di maksud dengan falah yaitu kesuksesan yang hakiki berupa kebahagiaan dalam segi materiil dan spiritual serta tercapainya kesejahteraan dunia dan akhirat.

(Sudarsono, 2002:105) Dalam pelaksanaannya sistem perekonomian syariah memiliki beberapa prinsip-prinsip perekonomian yang harus dipenuhi yaitu : 
a. Segala macam sumber daya yang ada dipandang sebagai titipan atau pemberian dari Allah SWT kepada mahluknya.

b. Islam hanya mengakui hak pemilikan pribadi dalam batas-batas tertentu saja, sehingga meminimalisair adanya kesenjangan.

c. Kekuatan utama dari perkonomian syariah terletak pada kerja sama.

d. Perkonomian Syariah menolak adanya akumulasi kekayaan yang hanya dapat dikuasai oleh segelintir orang saja.

\section{METODOLOGI PENELITIAN}

Untuk mendapatkan data yang akurat, maka data yang diperlukan dalam penyusunan penelitian ini akan diperoleh dengan cara melakukan berbagai kegoatan yang sekiranya dapat mendukung terselesaikannnya penelitian, antaralain sebagai berikut:

\section{Jenis Penelitian}

Jenis penelitian yang digunakan oleh peneliti dalam melakukan penelitian ini adalah penelitian kualitatif, yaitu suatu penelitian yang dimaksudkan untuk memahami segala aspek yang dialami oleh subjek penelitian dengan cara mendeskripsikan dalam bentuk tulisan, dan dengan memanfaatkan berbagai metodemetode alamiah.

\section{Metode Pengambilan Data}

Metode pengambilan data yang digunakan dalam penelitian ini adalah sebagai berikut:

1. Kepustakaan atau kajian literasi

Yaitu tim peneliti akan mengkaji inti permasalahan melalui referensi-referensi berupa literatur-literatur yang berkaitan serta relevan dengan penelitian ini. e. Perkonomian Syariah dapat menjamin kepemilikan masyarakat dan penggunaannya agar dapat direncanakan untuk kepentingan banyak orang.

f. Sebagai hambanya, seorang muslim harus takut kepada Allah SWT dan hari akhirat kelak.

g. Zakat wajib dikeluarkan atas kekayaan pribadi yang telah mencapai nisab (batasan).

h. Islam mengharamkan atau melarang riba dalam segala bentuk.

\section{Observasi}

Ialah rangakian berbagai macam aktivitas yang dilakukan oleh peneliti terhadap suatu proses atau objek dengan tujuan untuk dapat memahami hal tersebut berdasarkan pengetahuan dan gagasan yang diketahui sebelumnya kemudian memadukannya.

\section{Jenis dan Sumber Data Penelitian}

Data merupakan keterangan atau gambaran yang berkaitan dengan suatu hal atau fakta yang bilamana data tersebut dapat diolah dengan baik dan benar maka ia akan menghasilkan suatu informasi. Berdasarkan sumber-sumbernya, data dapat dikelompokkan menjadi dua, yaitu Data primer dan Data sekunder. Data primer ialah data penelitian yang diperoleh langsung dari sumber asli atau tidak melalui suatu perantara yang perlu di olah lebih lanjut serta dikembangkan dengan pemahaman peneliti itu sendiri. Sedangkan data sekunder ialah data penelitian yang diperoleh denagn tidak langsung yaitu melalui media perantara atau diperoleh dan dicatat oleh pihak lain. Data sekunder pada umumnya berupa catatan, bukti, atau laporan historis yang disusun dalam arsip 
data dokumen kemudian ada yang dipublikasikan da nada yang tidak dipublikasikan.

\section{Teknik Pengolahan dan Analisis Data}

Setelah peneliti mengumpulkan datadata yang sekiranya diperlukan dalam penelitian, peneliti mengolah data-data tersebut dalam penelitian yang bersifat deskriptif analisis, yaitu metode yang dilakukan untuk menyelesaikan atau memecahkan suatu permasalahan dengan cara mengumpulkan data, menyusun, mengklarifikasikannya, serta menganalisis dan menguraikannya. Sehingga permasalahan yang terdapat pada penelitian ini dapat dideskripsikan berdasarkan data yang diperoleh kemudian dianalisis sebagai suatu gagasan yang menarik untuk ditampilkan.

\section{Instrumen Penelitian}

Adapun alat-alat yang digunakan untuk menukung penelitian in adalah:
1. Buku memo dan alat tulis, digunakan tim peneliti sebagai media untuk mencatat beberapa kutipan dari literature, serta hasil dari observasi dan wawancara agar mempermudah peneliti dalam pengumpulan data.

2. Laptop, digunakan tim peneliti sebagai media inti dalam menunjang keberlangsungan proses penelitian ini.

\section{Waktu dan Lokasi Penelitian}

Penelitian ini dilakukan pada bulan awal bulan Desember 2018 sampai akhir bulan Desember 2018 yang merupakan musim penghujan. Penelitian ini merupakan penelitian yang akan dilaksanakan di Universitas Ibn Khaldun Bogor sebagai salah satu lembaga pendidikan dimana terdapat sebagian dari civitas akademikanya ikut berperan sebagai pelaku ekonomi. Beralamat di Jln. Kh. Sholeh Iskandar, Km 2 Kedung Badak, Tanah Sareal Bogor, Jawa Barat, Indonesia. 


\section{DAFTAR PUSTAKA}

Annaisabiru, Aulia. 2018. Pengertian Ekonomi Syariah dan Karakteristiknya.

https://blog.ruangguru.com/pengertia n-ekonomi-syariah-dan-

karakteristiknya . Diakses 18

Desember 2018.

Blogpengertian.com. 2017. Pengertian Ekonomi dan Kegiatan Ekonomi, http://blogpengertian.com/pengertian -ekonomi-dan-kegiatan-ekonomi/\# . Diakses 18 Desember 2018.

J. Lexy Moleong, Metode penelitian Kualitatif, Bandung : PT. Remaja Rosda Karya, 2000.

Maxmanroe.com. 2018. Kesenjangan Sosial Ekonomi: Pengertian, Faktor Penyebab, Dampak, dan Contohnya. https://www.maxmanroe.com/vid/sos ial/pengertian-kesenjangan-

sosial.html . Diakses 20 Desember 2018.

Riadi, Muchlisin. 2016. Pengertian, Tujuan, Prinsip dan Manfaat Ekonomi Syariah. https://www.kajianpustaka.com/2016 /09/pengertian-tujuan-prinsip-danmanfaat-ekonomi-syariah.html Diakses 18 November 2018.

Sowadji, Jusuf. Pengantar Metodologi Penelitian. Jakarta: Mitra Wacana Media, 2012.

Tanjung Hendri dan Abrista Devi, Metodologi Penelitian Ekonomi Islam, Jakarta: Granata Publishing, 2013. 